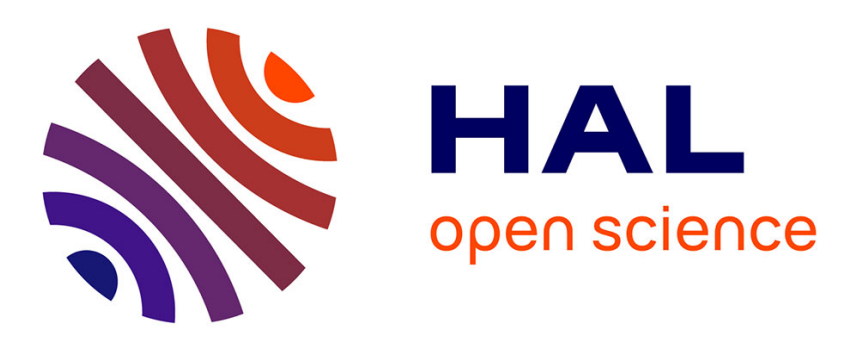

\title{
Current situation and future implementation of safety curricula for chemical engineering education in France
}

Laurent Perrin, A. Laurent

\section{To cite this version:}

Laurent Perrin, A. Laurent. Current situation and future implementation of safety curricula for chemical engineering education in France. Education for Chemical Engineers, 2008, 3 (2), pp.e84 e91. 10.1016/j.ece.2008.08.001 . hal-01925932

\section{HAL Id: hal-01925932 \\ https://hal.univ-lorraine.fr/hal-01925932}

Submitted on 30 Nov 2018

HAL is a multi-disciplinary open access archive for the deposit and dissemination of scientific research documents, whether they are published or not. The documents may come from teaching and research institutions in France or abroad, or from public or private research centers.
L'archive ouverte pluridisciplinaire HAL, est destinée au dépôt et à la diffusion de documents scientifiques de niveau recherche, publiés ou non, émanant des établissements d'enseignement et de recherche français ou étrangers, des laboratoires publics ou privés. 


\title{
CURRENT SITUATION AND FUTURE IMPLEMENTATION OF SAFETY CURRICULA FOR CHEMICAL ENGINEERING EDUCATION IN FRANCE
}

\author{
L. PERRIN * and A. LAURENT \\ Laboratoire des Sciences du Génie Chimique, Nancy - Université, CNRS, INPL, ENSIC \\ 1 rue Grandville, BP 20451, F-54001 Nancy Cedex.
}

\begin{abstract}
The paper describes an overview of the curricula concerning the safety and loss prevention courses delivered in the three following French departments of chemical engineering: Ecole Nationale Supérieure des Industries Chimiques de Nancy (ENSIC), Ecole Nationale Supérieure des Ingénieurs en Arts Chimiques et Technologiques de Toulouse (ENSIACET) and Ecole Nationale Supérieure en Génie des Technologies Industrielles de Pau (ENSGTI).

The arguments to introduce safety in the chemical engineering were first examined. The two main ways to teach safety, health and loss prevention concepts were then discussed. The detailed content of the courses was reported and compared with the recommendations of EFCE Bologna (I), of IChem (UK) and of Dechema GVC (D) guidelines. The proposed core compulsory curricula and the optional or elective courses were formulated according to the first and second cycle degrees European system, with the corresponding European Credit Transfer Unit (ECTU).

Finally an evaluation of the safety education experimented in the three chemical engineering departments was commented. Some propositions concerning the amelioration and the future development particularly from the point of view of the ethics and social process of safety were suggested, but the challenge is strong.
\end{abstract}

Keywords: safety; education; loss prevention; chemical engineering.

*Correspondence to: Dr. L. Perrin, Laboratoire des Sciences du Génie Chimique, Nancy - Université, CNRS, ENSIC, INPL, 1 rue Grandville, BP 20451, F - 54001 Nancy Cedex, E-mail : Laurent.Perrin@ensic.inpl-nancy.fr 


\section{INTRODUCTION}

The importance of safety and loss prevention has been underlined by a number of major chemical disasters. Those at Feyzin (1966), Flixborough (1974), Seveso (1976), Mexico City (1984), Bhopal (1984), Schweitzerhall Basel (1986), Port Herriot Lyon (1987), Pasadena (1989), Blaye (1997), AZF Toulouse (2001), Buncefield (2005) and Texas City (2005) for example are the best known, but there have been several others with death tolls.

Some of these accidents have particular impact in the Continental Europe. The trend has been particularly in France for petrochemical, heavy chemical, fines chemical, food and pharmaceutical industries to urge universities to teach safety and for professional bodies to introduce a requirement that safety and loss prevention be part of the academic curriculum. The challenge was to develop a way to improve the ability of chemical engineers to integrate a widespread safety culture.

This paper describes an overview of the actual curricula concerning the safety and loss prevention courses delivered in the three following French departments of chemical engineering: Ecole Nationale Supérieure des Industries Chimiques de Nancy (ENSIC), Ecole Nationale Supérieure des Arts Chimiques et Technologiques de Toulouse (ENSIACET) and Ecole Nationale Supérieure en Génie des Technologies Industrielles de Pau (ENSGTI).

\section{WHY TO TEACH SAFETY IN CHEMICAL ENGINEERING?}

Harvey (1984) has stated the justification to include safety in chemical engineering curriculum as following: «It is important that students be introduced to the concept of inherently safer design and that they realize that safety in plant operation must be considered right at the start of the design study. Process safety must be taught in a rigorous, stimulating way by staff of appropriate 
experience. Departments which initially do not have this expertise may need to use the services of experts from other universities, industry and consulting firms. By virtue of the nature of processes which give rise to major hazards, it is the chemical engineer who often fills the position of responsible person in the design or operation of plant».

Kletz (1988) advanced three principal arguments to support this view. One is the importance of treating safety from the outset as an integral part of the design of plant and of aiming for inherently safer design. Another is that whatever use he may make of other subjects taught at university, any practising chemical engineer will be involved in safety matters. He has a moral and legal responsibility and will probably be faced with issues from the first day. The third is that safety and loss prevention involve basic principles.

The extent to which safety and loss prevention rank as a mainstream subject in chemical engineering has been examined by Marshall (1991). He argues that to qualify a subject must meet the following criteria. It should:

(a) be acknowledged as such by academic culture,

(b) be recognized as relevant by students,

(c) be intellectually demanding,

(d) comprise a well established corpus of knowledge, organized on clearly defined unifying principles,

(e) be highly quantitative and thus capable of being subjected to mathematical analysis,

(f) possess a content and unifying principles set out in authoritative textbooks,

(g) be taught by specialists,

(h) be a compulsory subject which must normally passed and

(i) be examined formally.

He goes on to consider the extent to which safety and loss prevention now meet these criteria. 


\section{WHEN TO TEACH SAFETY IN CHEMICAL ENGINEERING?}

As Europe is implementing the Bologna three cycle degrees system, it would be useful to present the survey for a French "Safety, Health and Environment" education in a Bologna type study organization. This three stages structure will also facilitate one of the goals of Bologna process such as more and simple exchange in Europe during studies. The French existing structure is based on three main cycles of Licence - Master - Doctorate (LMD) equivalent to Bachelor's Master's - Doctorate Model. The situation of the three examined French chemical engineering departments in the Bologna process is scheduled in the figure (1).

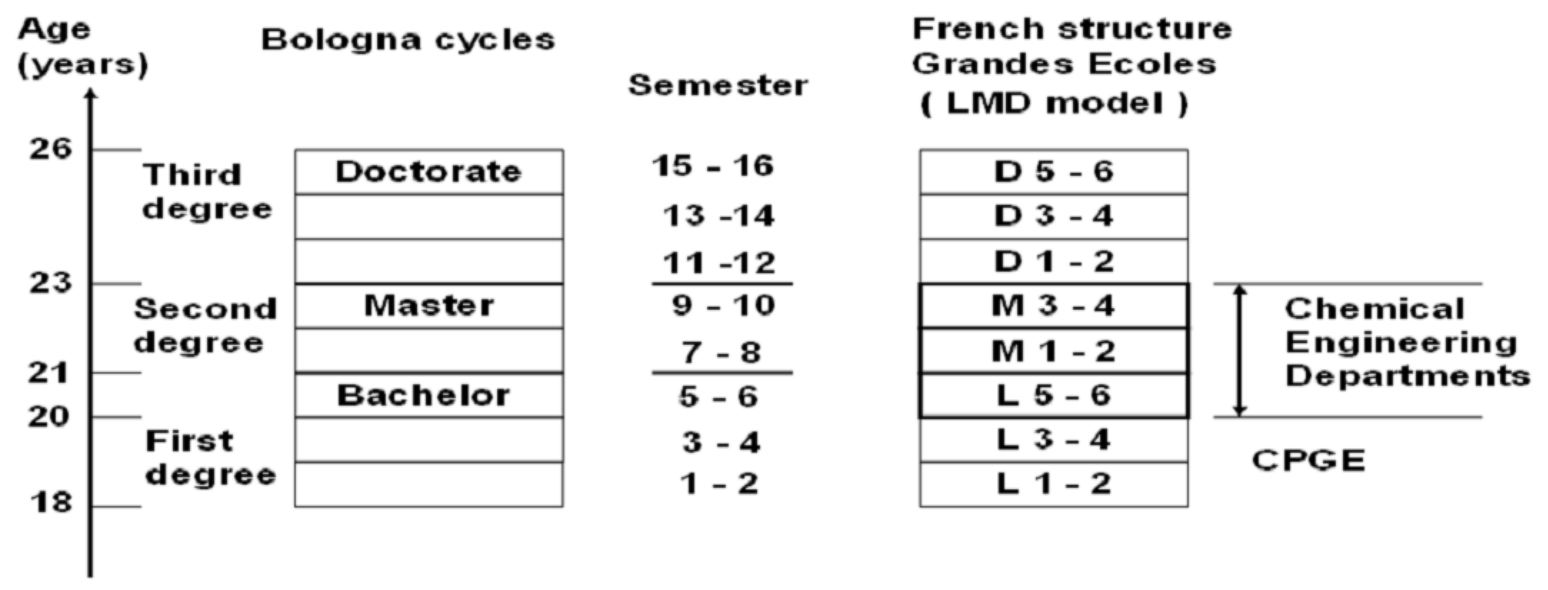

Figure (1) - Situation of the French chemical engineering departments in the Bologna process.

The two semesters L5 and L6 of the French departments are equivalent to the two last semesters of the three years first degree. The four semesters M1 to M4 correspond with the two years second degree. The teaching approach of SHE is then developed during the three years of the curriculum. At the present time, the inclusion of safety and loss prevention over the three year period of the curriculum is shown in table (I). 
Table (I) - General overview of the inclusion of safety and loss prevention over the three year period of the curriculum.

\begin{tabular}{|c|c|c|c|c|}
\hline Year & Semester & NANCY & PAU & TOULOUSE \\
\hline \multirow[t]{2}{*}{1} & L5 & $\begin{array}{l}\text { Safety awareness in } \\
\text { laboratory work } \\
\text { course. } \\
\text { Safety of external } \\
\text { contractors (individual } \\
\text { certification level \#1) }\end{array}$ & $\begin{array}{l}\text { Safety awareness in } \\
\text { laboratory work course }\end{array}$ & $\begin{array}{l}\text { Initiation courses }(18 \mathrm{hr}) \\
\text { ECTS }=2\end{array}$ \\
\hline & L6 & $\begin{array}{l}\text { Initiation courses } \\
\text { (12hr) }\end{array}$ & & \\
\hline \multirow[b]{2}{*}{2} & M1 & & & $\begin{array}{l}\text { Core compulsory } \\
\text { courses }(18 \mathrm{hr}) \\
\text { ECTS }=1\end{array}$ \\
\hline & M2 & $\begin{array}{l}\text { Core compulsory } \\
\text { courses ( } 42 \mathrm{hr} \text { ) } \\
\text { ECTS }=4\end{array}$ & $\begin{array}{l}\text { Core compulsory } \\
\text { courses }(49 \mathrm{hr}) \\
\text { ECTS }=6\end{array}$ & \\
\hline \multirow[t]{2}{*}{3} & M3 & $\begin{array}{l}\text { Design project } \\
\text { Industrial training } \\
\text { Core compulsory } \\
\text { courses ( } 30 \mathrm{hr} \text { ) } \\
\text { ECTS }=2 \\
\text { Safety of external } \\
\text { contractors (individual } \\
\text { certification level \#2) }\end{array}$ & \multirow[t]{2}{*}{ Industrial training } & $\begin{array}{l}\text { Elective courses } \\
(222 \mathrm{hr}) \\
\text { ECTS }=15\end{array}$ \\
\hline & M4 & & & $\begin{array}{l}\text { Design project } \\
\text { Industrial training }\end{array}$ \\
\hline
\end{tabular}

\section{HOW TO TEACH SAFETY IN CHEMICAL ENGINEERING?}

A question that should be answered right at the beginning is: Should the safety and hazard aspects be

- included as part of all chemical engineering courses?

- taught as a separate full course?

The final choice depends upon the philosophy teaching of each department, but the following points should be considered. The first way has an advantage in that it can be coordinated with the rest of course material. Safety can serve as an integrating factor in course. Table (II) illustrates 
some examples of the links between safety topics and regular subjects in chemical engineering curriculum.

Table (II) - Some examples of the links between safety topics and regular subjects in chemical engineering curricula (Lees, 1996; IChemE, 1990).

\begin{tabular}{|l|c|}
\hline \multicolumn{1}{|c|}{ SAFETY TOPICS } & REGULAR SUBJECTS \\
\hline Chemical hazards and toxicity & Chemistry \\
\hline $\begin{array}{l}\text { Explosion - Explosion energy - Adiabatic } \\
\text { flame temperature - Flammability limits ... }\end{array}$ & Fluid mechanics \\
\hline $\begin{array}{l}\text { Emission - Flashing liquids - Relief valve } \\
\text { discharge - Venting - Dispersion }\end{array}$ & Heat transfer \\
\hline Fire - Vaporization of cryogenic liquids... & Mass transfer \\
\hline $\begin{array}{l}\text { Inherently safer design of separation } \\
\text { processes }\end{array}$ & Simultaneous heat and mass transfer \\
\hline Vaporization of volatile liquids & Social sciences \\
\hline $\begin{array}{l}\text { Public perception and social acceptance of } \\
\text { risk - Operator reliability - Human factor... }\end{array}$ & Chemical reaction engineering \\
\hline $\begin{array}{l}\text { Reaction runaway - Inherently safer design } \\
\text { of chemical reactors }\end{array}$ & \\
\hline
\end{tabular}

This way of integration could be continual reinforcement over a three years period of curriculum in France. But there are problems in dealing only with other subjects. It cannot be expected that staff across the whole discipline will have the necessary interest, knowledge and experience. More such treatment is unlikely to get across the unifying principles. At the present time this way is ever in France the most difficult to implement because the lack of faculty members with sufficient background and interest to teach such material.

These latter arguments have weight and the tendency appears to be promoting a separate course on safety. In this second way, teaching a separate full course, the above disadvantages would disappear; the course would be more coherent and could better coordinate. We believe that the main advantage of a separate course is that such course can concentrate on the subject and especially present a systemic approach. 


\section{WHAT TO TEACH SAFETY IN CHEMICAL ENGINEERING?}

The answer is not trivial. As a matter of fact the fundamental problem lies in the basically "vertical" training given to chemical engineers, since those are taught in narrow and well-defined specialised fields. Now HSE definitely requires a horizontal approach: there is a need for such a horizontal vision and integration of knowledge and expertise. This suggests actions to be taken to make trainers aware of this multidisciplinary approach. In practice, chemical engineers have to consider complex situations involving different disciplines. Therefore, training is moving progressively to a more integrated approach, involving concepts from a number of disciplines (including social sciences and humanities) to expand the perspectives of chemical engineers and to promote a multidisciplinary approach to decision-making. At first we introduce an initiation with many examples of systemic approach and particularly the systemic model of hazard (Laurent, 1999; Perilhon et al., 2001).

To treat a phenomenon perceived as a complex system consists to establish the fact that the knowledge of this phenomenon is subordinated to the knowledge of the parts that make the whole, of the interactions between these parts, of the interactions with the environment and of the objectives of the observer or actor of the whole. The systemic approach proposes methodological principles for the investigation of natural and artificial systems with the aim of improving their conception, their functioning and their management. The Analysis Methodology for Malfunctions in Systems (acronym MADS in French) model consider installation, hardware, software, humans, management decision-making and organizational design as an integrated whole. The hazard analysis techniques based on this expanded model provide a means for obtaining the information necessary to design safety into the system and to determine the most critical parameters to monitor during the operations and how to respond to them. The reference model called "hazard 
process" put into relation a danger source system and a target system by means of a hazard flux within an active environmental field. Figure (2) illustrates the general systemic MADS model.

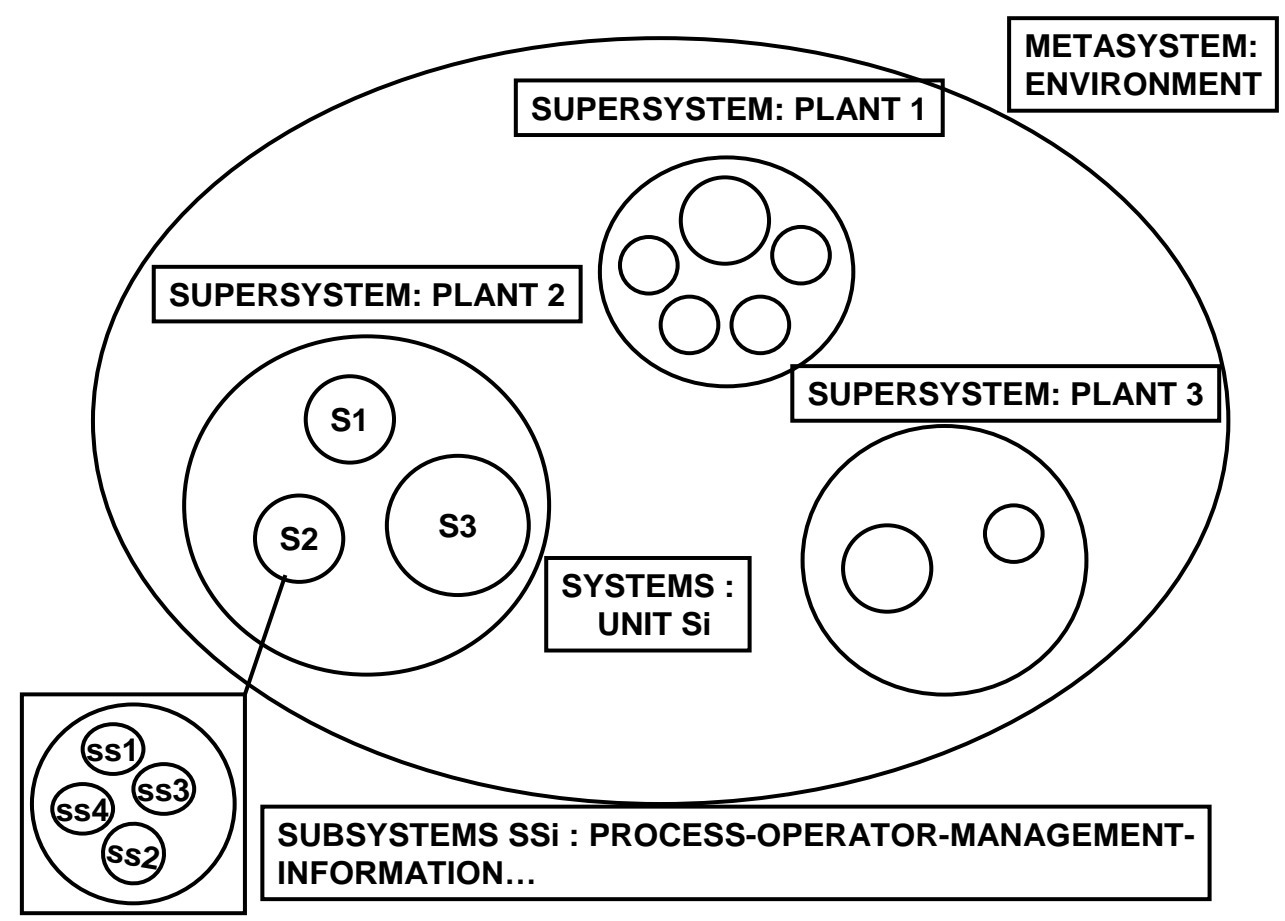

Figure (2) - Illustration of the systemic MADS model (Laurent, 1999; Perilhon et al., 2001).

Figure (3) shows a schematic view of the reference model of hazard process (Laurent, 1999; Perilhon et al., 2001). 


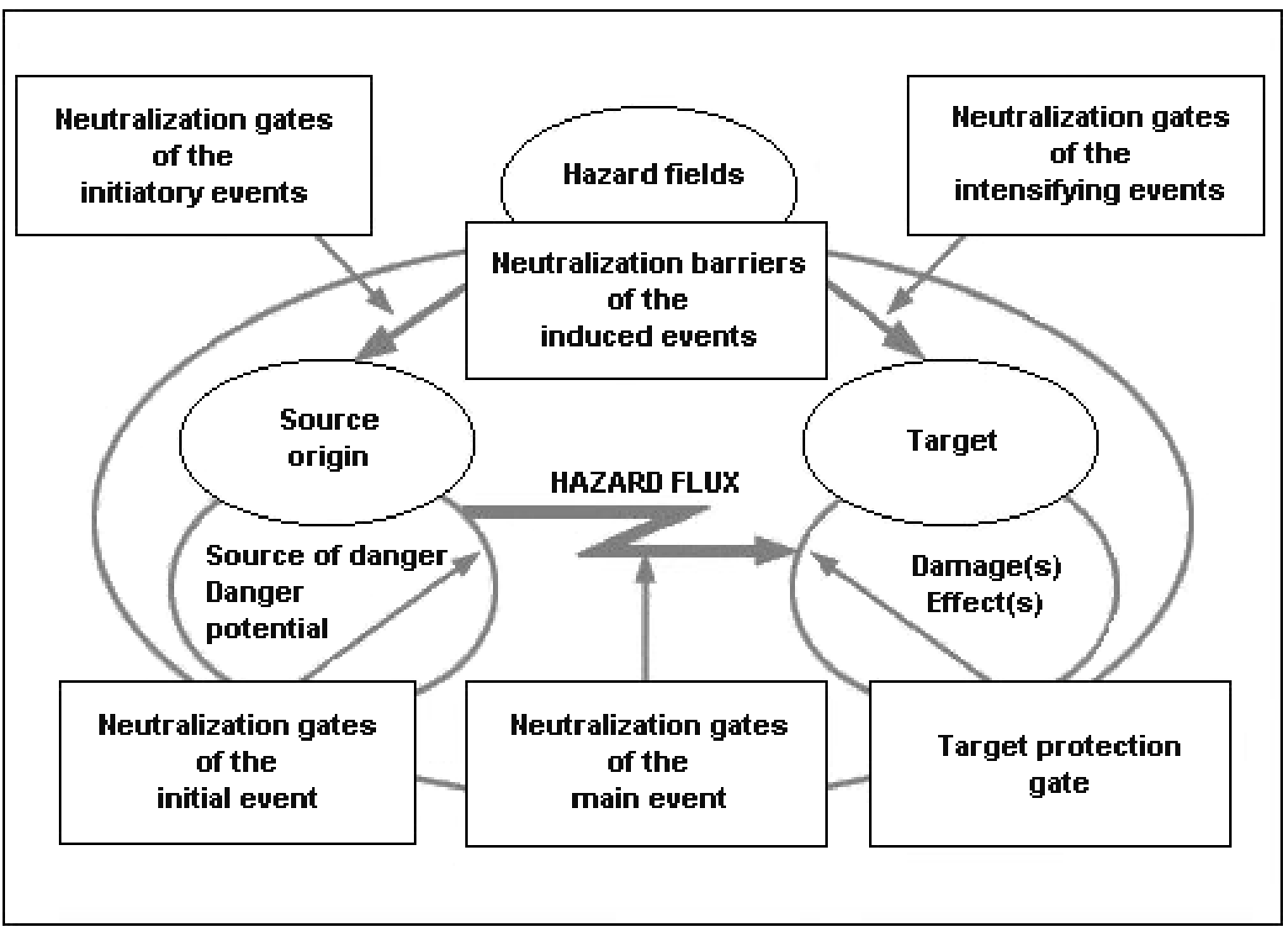

Figure (3) - Schematic view of the reference model of hazard process (Laurent, 1999; Perilhon et al., 2001).

During the semester L5 of the first year, chemical process safety is introduced in the three departments via existing laboratory work courses in chemistry and chemical engineering. For each cycle of experiments safety procedures for the laboratory and pilot plant work courses are reviewed. Plant visits and summer positions for worker training that emphasize some aspects of safety and health are organized for all students.

After that the aim of the general content of the safety courses is made up of the following three general subject matters: 
- Technical knowledge (including such aspects as definitions, risk assessment methodologies, accident analysis, and statistics and probability);

- Organisational knowledge (such as roles and responsibilities of various stakeholders, economic/financial aspects, relevant laws and regulations, business and safety management systems, and decision-making processes);

- Social/human knowledge (including risk communication, human factors and very soon ethical issues).

Our detailed list of course topics is similar to many accounts of practice in particular safety courses given in the literature (Kletz, 1984; Kaufmann, 1987; Crowl and Louvar, 1988; Levitzky, 1988; Fleischman, 1988; Gupta, 1989; Nolan, 1989; Fleischman, 1991; Laurent, 1993; King, 1998; Sheppard, 1998; Louvar and Hendershot, 2003; Papadki, 2007 and Ferjencik, 2007). The content of the core course was proposed in agreement with the safety and environmental guidelines recommended by the Accreditation Committee of the Institution of Chemical Engineers (IChemE, 1990). The Safety Health and Environment Committee (SHEPC) of IChemE decided to promote a matrix approach that divided the topics into basic principles and design project, special topics as well as integral with other topics, mandatory integral, mandatory separate and optional topics (Smith, 1997). In the same way the comparison of the main content is similar with the too much detailed guidance entitled « Lehrprofil Sicherheitstechnik » proposed by the Dechema / GVC Committee «Sicherheitstechnik in Chemieanlagen » (Dechema/GVC, 1997). At last our proposed safety curriculum complies with the recommendations on the one hand of the simplified guide of the EFCE Working Party Education (Gillett, 2001) and on the other hand of the ECTS Bologna scheme (Pohorecki, 2005).

An example of the content of the core compulsory courses delivered in 2007 during the semester M2 at ENSIC Nancy is presented in table (III). Note that the lecture part of the course was given 
weekly in two successive sessions of 90 minutes. A written examination forces students to read the courses book. We give a three hours open book exam.

Table (III) - Overview of the ENSIC Nancy course lectures and tutorials in 2007 during the semester M2.

\begin{tabular}{|c|l|}
\hline Lecture & \multicolumn{1}{c|}{ Topic of lecture } \\
\hline $1-2$ & Basic concepts: hazard - risk - hazard rules \\
\hline $3-4$ & Rules and European legislation \\
\hline $5-6$ & Risk analysis methodologies \\
\hline $7-8$ & Inherently safer design \\
\hline $9-10$ & Preliminary hazard analysis PHA \\
\hline $11-12$ & Hazard and Operability method HAZOP \\
\hline $13-14$ & Gas and vapour explosions \\
\hline $15-16$ & Dust explosions \\
\hline $17-18$ & Runaway reactions: causes - characterization - prevention - vent sizing \\
\hline $19-20$ & Atmospheric dispersion \\
\hline
\end{tabular}

\begin{tabular}{|c|l|}
\hline Tutorial & \multicolumn{1}{c|}{ Topic of tutorial } \\
\hline 1 & Preliminary hazard analysis PHA \\
\hline 2 & Hazard and Operability method HAZOP \\
\hline 3 & Atmospheric dispersion \\
\hline
\end{tabular}

Another example of the content of the core compulsory courses delivered in 2007 during the semester M2 at ENSGTI Pau is presented in table (IV).

Table (IV) - Overview of the ENSGTI Pau course lectures and tutorials in 2007 during the semester M2.

\begin{tabular}{|c|l|}
\hline Lecture & \multicolumn{1}{c|}{ Topic of lecture } \\
\hline $1-2$ & Complexity - catastrophic events - case studies: Mexico and Bhopal \\
\hline $3-4$ & Basic concepts: hazard - risk - hazard rules \\
\hline $5-6$ & Risk analysis methodologies (1) \\
\hline $7-8$ & Risk analysis methodologies (2) \\
\hline $9-10$ & Gas and vapour explosions - Dust explosions \\
\hline $11-12$ & Runaway reactions: causes - characterization - prevention - vent sizing \\
\hline $13-14$ & Atmospheric dispersion \\
\hline $15-16$ & Evaluation of the risk and quantification \\
\hline
\end{tabular}

\begin{tabular}{|c|l|}
\hline Tutorial & \multicolumn{1}{|c|}{ Topic of tutorial } \\
\hline 1 & Preliminary hazard analysis PHA \\
\hline
\end{tabular}




\begin{tabular}{|l|l|}
\hline 2 & Hazard and Operability method HAZOP \\
\hline 3 & Fault and Event Trees FET \\
\hline 4 & Failure Mode Effect Analysis FMEA \\
\hline 5 & Atmospheric dispersion \\
\hline
\end{tabular}

An example of the main modules of the elective courses delivered in 2007 during the semester M3 at ENSIACET Toulouse is presented in table (V).

Table (V) - Example of the ENSIACET Toulouse elective courses in 2007 during the semester M3.

\begin{tabular}{|c|c|c|c|}
\hline Module & Topic of the module & Allocation (hr) & ECTS \\
\hline 1 & Cleaner processes & 37 & \multirow[t]{2}{*}{6} \\
\hline 2 & Safer processes & 37 & \\
\hline 3 & Rules and European legislation & 09 & \multirow{4}{*}{4} \\
\hline 4 & Human and organizational factors & 09 & \\
\hline 5 & Industrial pollutions & 37 & \\
\hline 6 & Health and safety at work & 28 & \\
\hline 7 & Quality assurance & 37 & \multirow[t]{2}{*}{5} \\
\hline 8 & Management systems & 28 & \\
\hline
\end{tabular}

Since 2004 the ENSIC Nancy is accredited to deliver the certification for the external contractors intervening on chemical sites (Seveso high-risk industrial sites). This double certification (level \#1 for an operator during the L5 semester; level \#2 at an engineer level during the M3 semester) is validated by the UIC (the French Chemical Industries Association) and is compliant with the ILO-OSH 2001 set of recommendations published in 2002 by the International Labour Organisation (ILO).

During this curriculum the students can obtain the certificate of first-aid worker. The organization of this certification, validated by the ministry for health, is at the ENSIC Nancy under the responsibility of the students association. The courses related to this possible certificate validation are fully integrated in the ENSIACET Toulouse curriculum. 


\section{WHICH TEACHERS TO TEACH SAFETY IN CHEMICAL ENGINEERING?}

The three departments presented in this document use three different strategies. The ENSIC Nancy decided to integrate this curriculum, and after having used during a few years outside contributors (industrial) decided to compose a teaching team of four teachers. Nowadays $95 \%$ of the courses are carried out by this team.

The ENSGTI Pau shares its curriculum 50/50 between courses carried out by teachers of its department and conferences carried out by industrialists.

The courses of the ENSIACET Toulouse are mainly carried out by lecturers external to the department.

\section{WHAT DEPTH TO TEACH SAFETY IN CHEMICAL ENGINEERING?}

We adapted one practical answer proposed by J.E. Gillett, then by S. F. de Azevedo to teach chemical engineering (Gillett, 2001; Azevedo, 2001). It was to consider SHE subjects in elements that reflected three stages of learning. The first stage is to provide a basic awareness (beginner level), a second stage to provide an increasing appreciation sufficient to work with subjects experts (practical level) and the third stage to provide the level of full understanding and expertise (expert level). The idea of considering these three levels may have helped with SHE curriculum design and also have utilized to introduce difficult SHE subjects gradually to assist a deeper better understanding. Like this the core SHE subjects, as for example basic concepts and risk analysis methodology, had to be taught in depth.

\section{WHAT TEACHING AIDS TO USE FOR SAFETY?}


For the particular subjects of HSE we used many aids to teaching available that can be categorized as follows:

- Vicarious experience: books (Crowl and Louvar, 1990; Kletz, 1990; Lees, 1996; AIChE/CCPS books and Laurent, 2003), videos (IChemE packages; AIChE SACHE materials) films, sound recording...used to generate awareness and for short term arousal during long teaching sessions.

- Models: laboratory experiments, demonstrations, case studies, project work, computerized models (Cameo, 1993), sequenced exercises, examples...widely used to provide insight and understanding of deeper knowledge.

- Dramatizations: films, novels, role playing (Verdel, 2006)...used to provide insight into subjective issues and to develop mindset.

- Automatic teaching devices: programmed learning modules (Perilhon, 1998; Fouchecourt, 2005), computerised teaching machines...best used for routine knowledge and procedures.

A first mandatory worker's training (one month at the end of the first year) and a second mandatory industrial training (4 to 6 months at the end of the second year) are another different and further approach to bringing HSE into the curriculum.

\section{CONCLUSION: POTENTIAL PROSPECTS IN THE FRENCH FUTURE SAFETY EDUCATION}

The education of chemical engineers in the principles of safety has been a priority in France for fifteen years. Although the integration of safety with chemical engineering education is important, it has not been sufficiently wide spread. It has been noted that a barrier to better integration safety is the already crowded nature of chemical engineering curricula and the 
continued pressure for the inclusion of new materials. There appears to be obstacles at least in the short term to its full integration. However that may be the next challenge in France will be to develop notable efforts for an extensive integration. Marshall (1990) supports a proposal for a better integrated approach concerning safety, occupational health and environmental protection with the constraint of social acceptability of the chemical and process industries. The proposition and the experience of Lemkowitz (1992) in the Delft University of Technology with the development of a unique program for integrating health, safety, environment and social aspects into chemical engineering education will be helpful for the potential application in France. The same author extends this multidisciplinary basically societal approach in relation with the concept of sustainability (Lemkowitz et al., 1999; Lemkowitz et al., 2000a and Lemkowitz et al., 2000b). At present we try to generate thoughts and opinions among the teachers to introduce an initiation to ethics in chemical engineering education. Indeed open-ended problems are the essence of any chemical engineering practice and a potential application cannot possibly be provided without going through ethical considerations, often ethical dilemmas. Now chemical engineering acts in a global market and therefore it is imperative that the students are prepared to work everywhere in the world where their expertise is needed. Ethics is not only about recognising ethical values, but also to realize how those can be interpreted and applied in a diverse cultural context. In an ideal pedagogical way, we would like to see ethics accessed implicitly as part of the assessment of almost each chemical engineering module. But this proposition raises the same difficulties as for teaching classical safety.

We tested first as introduction a simple approach proposed in the literature with the help of two safety and environmental scenarios that pose ethical problems (Mascone et al., 1991a and Mascone et al., 1991b). At the beginning of a course the students were asked to fill out two survey questionnaires; next they discussed the scenarios and the obtained answers in interaction 
with the session moderated by the teacher. The goal of the discussion was to get the students to consider and discuss the consequences of the various alternative actions. The evaluation of the session was useful but too pedagogically limited.

A more complete example of that opportunity was discussed in detail by Ocone (2005) with the proposition of two possible main broad routes to teach ethics. She feels to conclude that we do need to teach ethics, but the way we teach is open to interpretations, personal views and experience. In the same way, Lemkowitz et al. (2004) note in their industrial ecology teaching approach the necessity to distinguish between epistemological and ethical questions.

Finally what do we know and propose about the safety ethic? At the present time we try to apply the cohesive model of the safety ethic identified by Hill (2003). This model recapitulates the five following elements:

I value safety as a positive, integral part of my every day activities

I work safely by minimizing risks of injury and illness

I prevent at risk behaviour whenever I encounter it

I promote safety to others whenever possible

I accept responsibility for safety as a free act of caring for others

The detailed content of these elements is described in the reference (Hill, 2003). This simple model for the safety ethic provides the opportunity to strive to a new level of attention to safety. In conclusion, for the future French safety education, the potential application of several trends summarized as follows:

- contribute to learning safety programme in early chemical engineering curricula, particularly with the introduction of the inherent safety concepts

- improve knowledge of the field "health, safety and environment" with the strengthening of the role of science and engineering 
- improve awareness of ethical in safety and in risk management

- $\quad$ further the establishment of a safety culture

will be the main outlines for the requisite improvement of teaching safety in chemical engineering curriculum.

\section{REFERENCES}

AIChE, Center for Chemical Process Safety (CCPS), Process safety books and guidelines, http://www.aiche.org ; http://www.knovel.com/knovel2/publisher

AIChE, Safety and Chemical Engineering Education (SACHE), Process safety materials and programs deliverables, http://www.aiche.org

Azevedo S. F., 2001, Which education of chemical engineers in 2020? Chempor'01, $8^{\text {th }}$ Int. Chem. Engng. Conference, p.107-120, Aveiro, Portugal, 12-14 September 2001.

CAMEO, 1993, Manual of computer-aided management of emergency operations (CAMEO II), National Oceanic and Atmospheric Administration (NOAA), US Environmental Protection Agency (USEPA), COM 18, Euro 911, version française.

Crowl D. A. and Louvar J. F., 1988, Safety and loss prevention in the undergraduate curriculum - A dual perspective, Chemical Engineering Education, Spring, 74-79.

Crowl D. A. and Louvar J. F., 1990, Chemical process safety: fundamentals with applications, Ed. Prentice Hall, Englewood Cliffs, New Jersey, USA.

Dechema/GVC, 1997,Gvc-Fachausschuss «Sicherheitstechnik in Chemieanlagen », Lehrprofil Sicherheitstechnik, Franfurt am Main.

Ferjencik M., 2007, Best starting point comprehensive process safety education, Process safety Progress, 26(3),195202.

Fleischman M., 1988, Rationale for $\square$ incorporating health and safety into the curriculum, Chemical Engineering Education, Winter, 30-34.

$\square$ Fleischman M., 1991, Risk reduction in the chemical engineering curriculum, Chemical Engineering Education, Fall, 198-203.

Fouchecour M., 2005, e-learning rezorisque: management of risk, http://rezorisque.org, http://rezorisque.paris.ensam.fr/risque.php3

Gillett J.E., 2001, Chemical engineering education in the next century, Chem. Eng. Technol., 24, 6, 561-570.

Gupta J. P., 1989, A chemical plant safety and hazard analysis course, Chemical Engineering Education, Summer, 194-196.

Harvey B. H., 1984, Third report of the advisory committee on major hazards, London, HM Stationery Office (UK). Hill Jr R.H., 2003, The safety ethic: where can you get one?, Chemical Health \& Safety, May/June, 8-11.

IChemE, 1990, The Institution of Chemical Engineers, Guidelines for teaching of safety and loss prevention to undergraduates, Rugby, UK.

IChemE, Process safety training packages, http://www.icheme.org

Kaufmann D., 1987, Health, safety and loss $\square$ control topics in the senior design courses, Plant and Operations Progress, 6, 2, 73-76.

King J. A., 1998, Incorporating safety into a unit operations laboratory course, Chemical Engineering Education, Summer, 178-183.

Kletz T. A., 1984, Safety in design, $\square$ Chemical Engineering Progress, 80, 3, 11.

Kletz T. A., 1988, Should undergraduates be instructed in loss prevention?, Plant and Operations Progress, 7(2), 9598.

Kletz $\square$ T. A., 1990, Plant design for safety: a user-friendly approach, Ed. Hemisphere Publishing Corporation, New York, USA.

$\square$ Laurent A., 1993, Pour un enseignement de sûreté de fonctionnement des procédés dans les écoles d'ingénieurs de chimie et de génie chimique : l'expérience pédagogique acquise dans ce domaine par l'ENSIC NANCY, Assises 
internationales des formations universitaires et avancées dans le domaine des sciences et techniques du danger, INFORISK, Actes 149, Bordeaux, France.

Laurent A., 1999, Information feedback for improving safety and loss prevention courses on French chemical engineering education, ECCE 2, Montpellier, 5-7 October 1999, Chemical engineering education, Now teaching: safety, health and environment, Récents Progrès en génie des procédés, volume 13, N64, 537-544, Ed. Lavoisier Paris, France.

Laurent A., 2003, Sécurité des procédés chimiques: connaissances de base et méthodes d'analyse de risques, Ed. Lavoisier Tec \& Doc, Paris, France.

Lees F. P., 1996, Loss prevention in the process industries, Hazard identification and control, Second edition, Volumes I - II - III, Ed. Butterworth-Heinemann, Oxford (UK).

Lemkowitz S. M., 1992, A unique program for integrating health, safety, environment and social aspects into undergraduate chemical engineering education, Plant and Operations Progress, 11 (3), 140-150.

Lemkowitz S. M., Pasman H. J. and Harmsen G. J., 1999, Complementing safety, health and environment in chemical engineering education with the new paradigm of the 21st century : sustainability, 2nd European Congress of Chemical Engineering, Topic 11, Montpellier (F).

Lemkowitz S.M., Harsem G.H., Korevaar G; and Lameris G.H., 2000a, Implementation of sustainable development into industrial and university chemical engineering, 14 th International Congress of Chemical and Process Engineering (CHISA), Session: Chemical engineering education in $21^{\text {st }}$ century, Paper K3.3, 27-31 August 2000, Praha (CS).

Lemkowitz S.M., Pasmann H.J. and Schupp B.A., 2000b, Integration of safety, health, environment and societal questions into engineering education and industrial training, 14 th International Congress of Chemical and Process Engineering (CHISA), Session: Chemical engineering education in $21^{\text {st }}$ century, Paper K3.4, 27-31 August 2000, Praha (CS).

Lemkowitz S.M., Lameris G.H., Van der Voet E. and Nikoli'c I., 2004, An industrial ecology teaching approach suitable to all university students, International Conference on Engineering Education in Sustainable Development, EESD 2004, D. Ferrer-Balas, K.F. Mulder, J. Bruno and R. Sans (Eds), CIMNE and UPC, Barcelona (SP).

Levitzky J. J., 1988, Safety, health $\square$ and loss prevention in the undergraduate chemical engineering curriculum, Plant and Operations Progress, 7(3), 190-194.

Louvar J. F. and Hendershot D. C., 2003, SACHE: 17 years of promoting teaching of safety to chemical engineering students, Chemical Health \& Safety, September/October, 8-10.

Marshall V. C., 1991, Teaching process safety, The Chemical Engineer, August, 502, 30-31.

Mascone C.F., Santaquili A.G. and Butcher C., 1991, Engineering ethics: what are the right choices?, Chemical Engineering Progress, 61-64, April.

Mascone C.F., Santaquili A.G. and Butcher C., 1991, Engineering ethics: how ChEs respond, Chemical Engineering Progress, 73-82, 0ctober.

Nolan P.F., 1989, Safety and loss prevention teaching, J. Loss Prev. Process. Ind., 2(1), 3-4.

Ocone R., 2005, Should we teach ethics in chemical engineering? The Chemical Engineer, 24-29, November.

Papadaki M., 2007, Inherent safety, ethics and human error, Journal of Hazardous Materials,????

Perilhon P., 1998, Software MADS - MOSAR II, CD Rom, Fox Media.

Perilhon P., Leroux J.P., Perrin L. and Laurent A., 2001, Potentialités pédagogiques de la méthode MADS MOSAR pour la formation à l'analyse des risques, $8^{\text {ième }}$ Congrès Francophone de Génie des Procédés, Nancy, 17-19 Octobre 2001, Thème 6, Sûreté et sécurité: connaissances de base et analyse des risques, Récents Progrès en génie des procédés, 15(85), 101-106, Ed. Lavoisier Paris (F).

Pohorecki R., 2005, European Federation of Chemical Engineering recommendations for chemical engineering education in a Bologna two cycle degree system, September.

Sheppard C. M., 1998, Process safety in the curriculum, Chemical Engineering Education, Fall, 270-276.

Smith M. K., 1997, Safety Health and Environment $\square$ Committee, Institution of Chemical Engineers, A matrix of safety, health and environment topics for undergraduate courses, Rugby (UK).

Verdel T., 2006, Simulation of crisis and emergency management, March 24, 2006, http://www.thierry.verdel.com, http://www.mines.inpl-nancy.fr/ verdel/mode.php?id=simulation.php 


\section{LIST OF FIGURE CAPTIONS}

Figure (1) - Situation of the French chemical engineering departments in the Bologna process.

Figure (2) - Illustration of the systemic MADS model (Laurent, 1999; Perilhon et al., 2001).

Figure (3) - Schematic view of the reference model of hazard process (Laurent, 1999; Perilhon et al., 2001). 


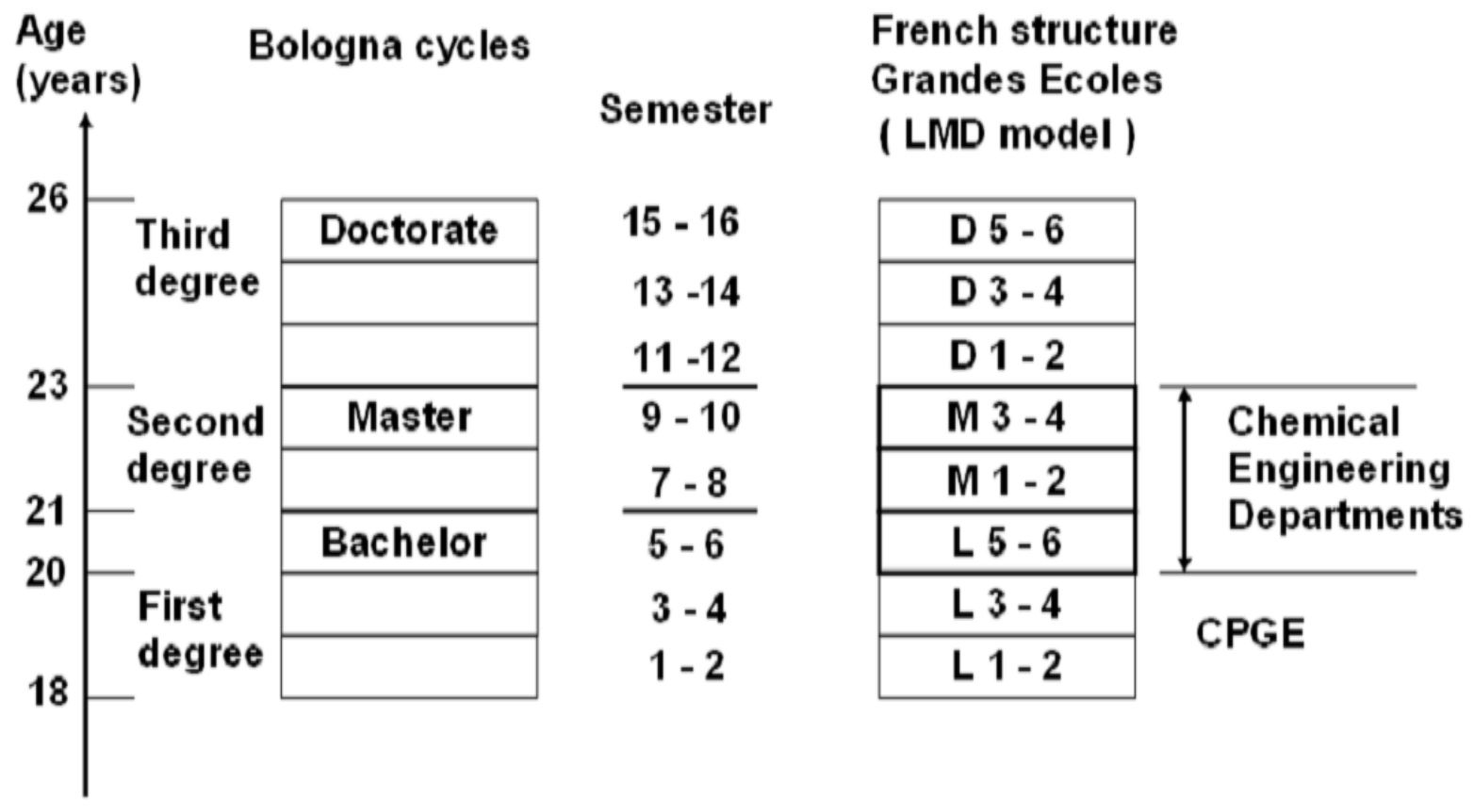

Figure (1) - Situation of the French chemical engineering departments in the Bologna process. 


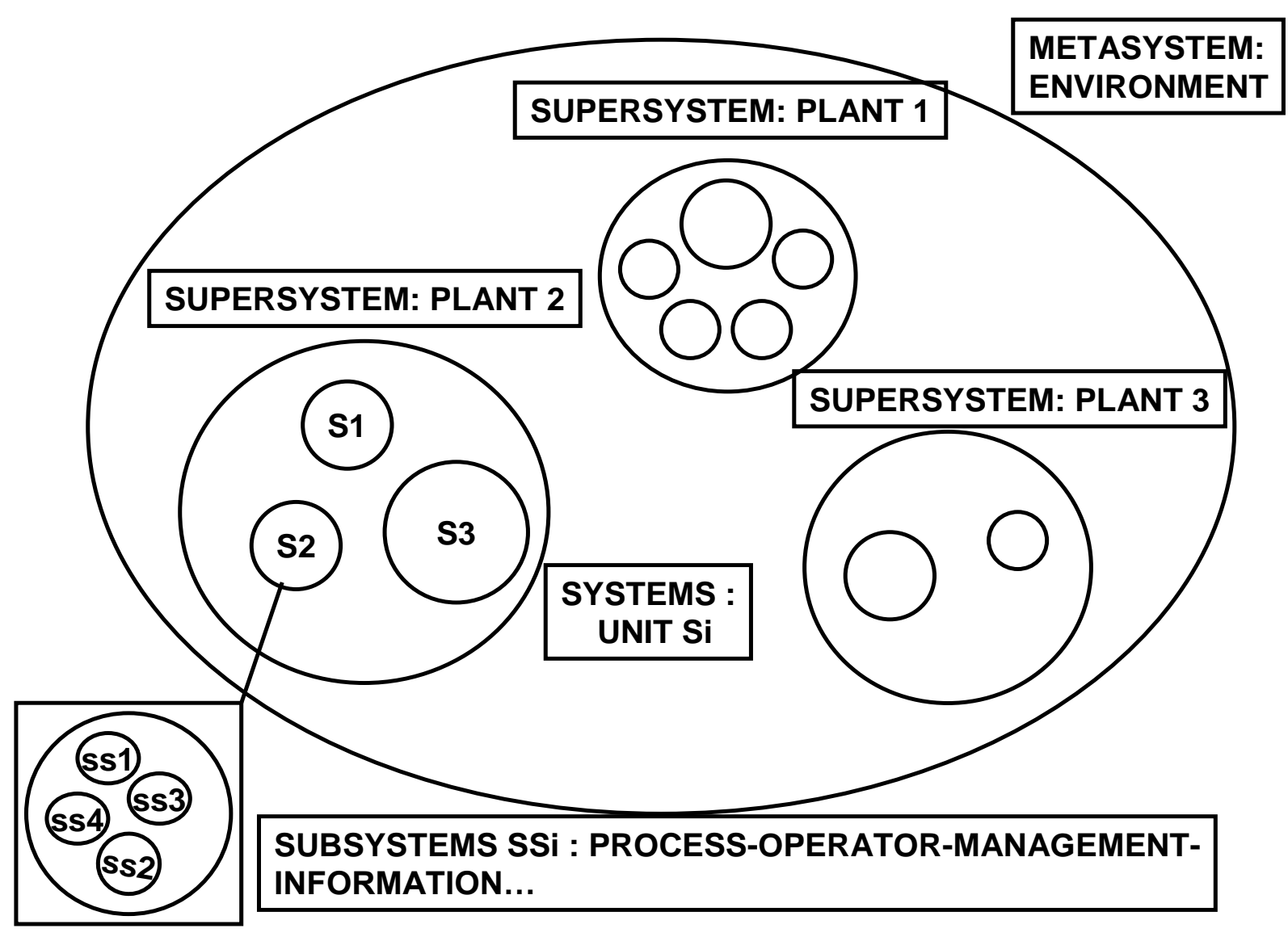

Figure (2) - Illustration of the systemic MADS model (Laurent, 1999; Perilhon et al., 2001). 


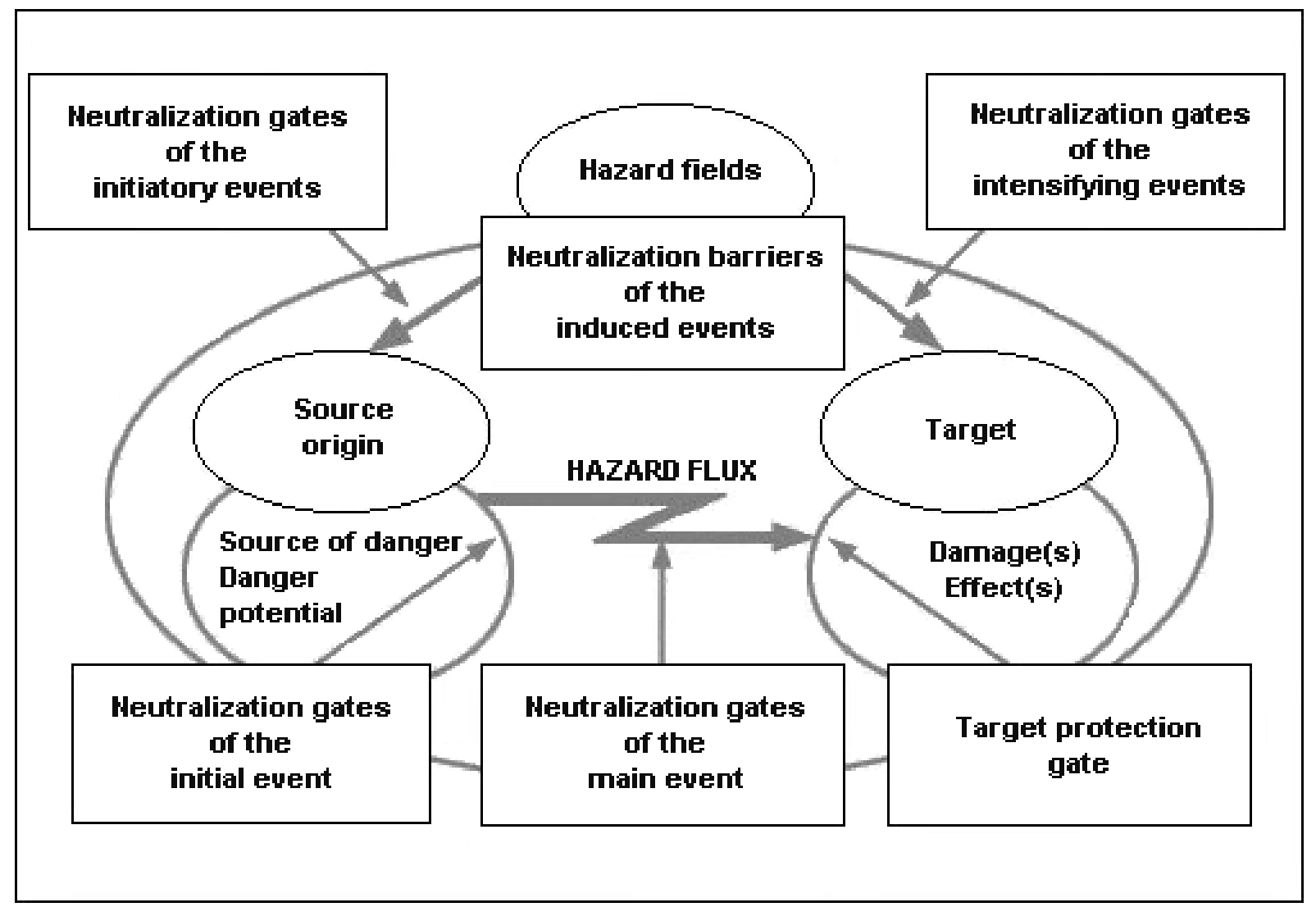

Figure (3) - Schematic view of the reference model of hazard process (Laurent, 1999; Perilhon et al., 2001). 